\title{
Analisis Potensi Jenis Longsor Berdasarkan Karakteristik Geomekanika Batuan di Kecamatan Patuk, Kabupaten Gunung Kidul, Daerah Istimewa Yogyakarta
}

\author{
Bandhar Aji Sukma Yudha ${ }^{1}$, Distika Pratiwi ${ }^{1}$, Tusyifa Rahmadanti ${ }^{1}$, \\ Thamzez Nuur Anom, ${ }^{1, a}$, Wisnu Aji Dwi Kristanto ${ }^{1}$ \\ ${ }^{1}$ Universitas Pembangunan Nasional Veteran Yogyakarta \\ ${ }^{a}$ corresponding author: Thamziz.n.a@gmail.com
}

\begin{abstract}
Kecamatan Patuk, Kabupaten Gunung Kidul is an area that has a large potential for landslides.The number of discontinuity area and weathering causing landslides Kecamatan Patuk and surrounding areas. This paper aims to identify the distribution of rocks in the form of geomechanical values that are used to predict the type of landslides. The research method used is literature research studies with secondary data collection. Rock Mass Rating (RMR) that are used as research material are weathering rate on rocks, RQD (Rock Quality Designation), the compressive strength of intact rock, and RMR (Rock Mass Rating). The results showed that 3 rock units that comprise the study area, from old to young, Tuffan Sandstone Unit, Sandstone Unit, and Andesite Breccia Unit. The research area was divided into 5 geological engineering units based on the RMR, andesite breccia unit with excellent rock quality (83), andesite breccia unit 2 with moderate rock quality (48-55), tufa unit with poor good rock quality (36-80), tufan sandstone unit with moderate - good rock quality (53-63) and sandstone unit with good rock quality (62). Potential types of landslides in the research based on geomechanical rock kinematics analysis, are sliding type with sliding form (circular failure), plane failure, and wedge failure. Disaster mitigation is needed to reduce or eliminate the risk of landslides in the research area.
\end{abstract}

Keywords: landslides, geomechanics, rock quality designation (RQD), weathering levels.

ABSTRAK
Kecamatan Patuk, Kabupaten Gunung Kidul merupakan daerah yang memiliki potensi kejadian tanah longsor cukup besar. Banyaknya bidang diskontinuitas serta pelapukan menjadi faktor utama penyebab tanah longsor pada daerah Patuk dan sekitarnya. Tulisan ini bertujuan mengidentifikasi potensi jenis longsoran berdasarkan nilai geomekanika batuan. Metode penelitian yang digunakan yaitu penelitian dengan studi literatur dengan metode pengumpulan data. Parameter geomekanika batuan yang digunakan sebagai bahan penelitian berupa tingkat pelapukan pada batuan, kerapatan bidang diskontinuitas $(R Q D)$, nilai kuat tekan batuan utuh dan pembobotan massa batuan $(R M R)$. Hasil penelitian menunjukkan terdapat 3 satuan batuan yang menyusun daerah penelitian yaitu satuan batupasir tufan, satuan batupasir, serta satuan breksi andesit. Daerah penelitian dibagi menjadi 5 satuan geologi teknik berdasarkan RMR, yaitu satuan breksi andesit 1 dengan kualitas batuan sangat baik (83), satuan breksi andesit 2 dengan kualitas batuan sedang (48-55), satuan tufa dengan kualitas batuan buruk - baik (36-80), satuan batupasir tufan dengan kualitas batuan sedang - baik (53-63) dan satuan batupasir dengan kualitas batuan baik (62). Potensi jenis longsoran pada daerah penelitian berdasarkan analisis kinematika geomekanika batuan yaitu berjenis longsoran gelinciran (sliding) dengan bentuk longsoran busur (cicular failure), longsoran bidang (plane failure), dan longsoran baji (wedge failure). Perlu dilakukan mitigasi bencana untuk mengurangi maupun meniadakan resiko bencana tanah longsor pada daerah penelitian

Kata Kunci: longsoran, geomekanika, rock quality designation (RQD), tingkat pelapukan.

\section{PENDAhUluAN}

Pulau Jawa termasuk jalur tektonisme sangat aktif di dunia yaitu pertemuan dua lempeng besar. Lempeng Indo-Australia menyusup di bawah lempeng benua Eurasia membentuk suatu batas konvergen berupa zona subduksi. Subduksi lempeng mengakibatkan suatu tubuh batuan terkena berbagai macam gaya yang sangat kompleks sehingga menghasilkan bidang diskontinuitas pada batuan. Bidang diskontinuitas meliputi kehadiran kekar, bidang perlapisan, struktur geologi, zona lapukan batuan dan bidang yang memutus tubuh batuan lainnya. Semakin besar dan kompleks gaya yang telah mengenai 
batuan maka semakin banyak bidang diskontinuitas yang muncul. Bidang diskontinuitas pada batuan akan mempengaruhi kekuatan batuan. Semakin kecil kekuatan batuan maka semakin banyak bidang diskontinuitas yang memotong massa batuan sehingga dapat menyebabkan terjadinya longsoran (Anwar et al.. 2018), selain itu semakin rapat bidang diskontinuitas akan lebih memudahkan air mudah masuk dan melapukan batuan (Kristanto et al., 2020). Adanya bidang diskontinuitas pada batuan menjadi hal yang perlu dipertimbangkan dalam perencanaan suatu wilayah atau konservasi lahan.

Gerakan massa tanah dan batuan adalah menuruni atau keluar lereng oleh suatu massa tanah atau batuan yang menyusun lereng, ataupun percampuran keduanya menjadi bahan rombakan, yang mengakibatkan terganggunya kestabilan tanah atau batuan penyusun lereng tersebut (Karnawati, 2005). Kejadian longsor mengakibatkan kerugian yang cukup besar. Frekuensi kemungkinan terjadinya bencana tanah longsor lebih besar dibanding kemungkinan terjadi bencana geologi lain. Salah satu upaya untuk mengurangi atau mencegah bencana longsor adalah dengan mengenali tanda-tanda yang dapat menyebabkan potensi longsor. Dalam kajian lanjut diperlukan peta kawasan rawan bencana tanah longsor guna memudahkan mitigasi pada masyarakat (Arsyad, 2017). Geomekanika batuan merupakan parameter pembobotan massa batuan berdasarkan nilai keteknikannya. Kajian geomekanika membahas mengenai klasifikasi geomekanika untuk batuan (kuat tekan, RQD), pembobotan massa batuan (Rock Mass Rating), pembobotan massa lereng (Slope Mass Rating), desain lereng stabil, dan daya dukung fondasi (Hirnawan et al., 2018).

Longsor terjadi karena gaya penggerak batuan lebih besar dari gaya penahan. Gaya penggerak ini merupakan manifestasi dari ketidakstabilan batuan. Pengujian kestabilan batuan dapat menggunakan metode uniaxial compressive strength (UCS) dan rock mass rating (RMR). Uniaxial compressive strength (UCS) dapat merepresentasikan kekuatan batuan terhadap tekanan yang menggambarkan nilai kondisi batuan untuk dapat menahan gaya yang diberikan sebelum mengalami penghancuran. Rock mass rating (RMR) mengukur kestabilan massa batuan terhadap pengaruh bidang diskontinuitas (spasi, kekasaran, lebar bukaan) (Dandy, 2015). Klasifikasi dengan metode RMR dapat dimanfaatkan dalam banyak bidang diantaranya untuk studi stabilitas lereng, studi terowongan, penambangan, dan studi pondasi sehingga klasifikasi ini bersifat praktis dan global (Bieniawski (1989). Pelapukan pada batuan juga merupakan faktor pengontrol gerakan massa tanah pada suatu wilayah. Tingginya tingkat pelapukan dipengaruhi oleh perubahan suhu yang sangat drastis dalam waktu yang cepat. Didukung dengan curah hujan yang sangat tinggi pada daerah tropis sebagai media pengikis serta media transport material hasil pelapukan ikut mendukung kecepatan pelapukan pada daerah tropis. Pelapukan akan mengubah sifat fisika dan kimia dari batuan. Komposisi penyusun dari batuan akan berubah menjadi unsur-unsur lain yang memiliki resistensi lebih rendah dari batuan induk. Tingginya tingkat pelapukan pada batuan merupakan suatu potensi gerakan massa tanah dan batuan (Titisari et al., 2019).

Tanah longsor merupakan salah satu bencana yang memiliki frekwensi kejadian yang tinggi di DIY, terutama di wilayah-wilayah yang rawan atau berpotensi terjadi tanah longsor (Nugroho, dkk 2019). Berdasarkan pantauan data rekaman kejadian bencana oleh badan nasional penanggulangan bencana (BNPB) di Kabupaten Gunung Kidul dari tahun 2000-2020 terdapat 93 kejadian bencana alam yang didominasi berupa tanah longsor (BNPB, 2020). Kecamatan Patuk, Kabupaten Gunung Kidul merupakan daerah yang memiliki potensi kejadian tanah longsor cukup besar. Umur batuan yang cukup tua, banyaknya bidang diskontinuitas serta pelapukan yang terjadi pada tingkat sedang - intensif menjadi faktor utama penyebab tanah longsor pada Daerah Patuk dan sekitarnya (Nugroho, 2010). Gejala gejala tanah longsor berupa tanah merekah sebenarnya sering di temukan pada Daerah Patuk, seperti yang terjadi pada Dusun Brongkol, Desa Purwodadi, Kecamatan Patuk, Kabupaten Gunung Kidul pada 8 Januari 2020. Rekahan tanah terbuka hingga $70 \mathrm{~cm}$ dengan kelurusan lebih dari $300 \mathrm{~m}$. Rekahan tersebut terjadi setelah hujan deras tiba dan membuat tanah jenuh air (Tribun Jogja, 2020). Melihat begitu besarnya potensi longsor di daerah tersebut sehingga perlu dilakukan suatu analisis mengenai 
keterkaitan aspek geomekanika batuan terhadap potensi longsor pada daerah tersebut. Tujuan dari penelitian yang ada di Kecamatan Patuk, Kabupaten Gunung Kidul ini adalah untuk mengetahui sebaran batuan, mengetahui nilai geomekanika dari setiap satuan batuan dan mengetahui potensi jenis longsor dari identifikasi nilai geomekanika batuan.

\section{METODE}

Metode penelitian yang digunakan untuk mengetahui potensi longsor berdasarkan geomekanika ini adalah dengan studi literatur. Data-data sekunder diperoleh dari berbagai sumber antara lain data literatur, jurnal, makalah, dan laporan penelitian sebelumnya. Data-data yag dimaksud adalah sebaran batuan dan sebaran keteknikan batuan (geomatika batuan). Geomekanika (mass rating) batuan merupakan parameter dalam menilai kualitas keteknikan batuan. Parameter yang dinilai dalam penelitian ini yaitu tingkat pelapukan (Tabel 1), rock quality designation (RQD) sebagai pengukur kualitas batuan (Tabel 2), nilai kuat tekan batuan utuh (Tabel 3), dan rock mass rating (RMR) (Tabel 4). Data-data sekunder yang diperoleh selanjutnya dianalisis secara analisis deskriptif, analisis deskriptif dilakukan untuk mengetahui potensi longsor berdasarkan nilai geomekanika dari setiap satuan batuan di Kecamatan Patuk, Kabupaten Gunung Kidul.

Tabel 1. Tingkat Pelapukan dan Deskripsinya klasifikasi ISRM Committee on Rock Classification

\begin{tabular}{cll}
\hline Tingkat & \multicolumn{1}{c}{ Jenis } & \multicolumn{1}{c}{ Deskripsi } \\
\hline I & Batuan Segar & $\begin{array}{l}\text { Kondisi batuan tidak ditemukan tanda lapuk. Sedikit ditemukan perubahan warna } \\
\text { pada bidang diskontinuitas. }\end{array}$ \\
\hline II & $\begin{array}{l}\text { Terlapukkan } \\
\text { Ringan }\end{array}$ & $\begin{array}{l}\text { Terjadi perubahan warna pada batuan dan bidang diskontinuitas dengan seluruh } \\
\text { material batuan mengalami perubahan warna akibat pelapukan. }\end{array}$ \\
\hline III & $\begin{array}{l}\text { Terlapukkan } \\
\text { Sedang }\end{array}$ & $\begin{array}{l}\text { Kondisi tubuh batuan kurang dari setengah menjadi tanah. Kondisi inti batuan } \\
\text { memperlihatkan perubahan warna atau masih segar. }\end{array}$ \\
\hline IV & Terlapukkan Kuat & $\begin{array}{l}\text { Kondisi tubuh batuan lebih dari setengah menjadi tanah. Kondisi inti batuan } \\
\text { memperlihatkan perubahan warna atau masih segar. }\end{array}$ \\
\hline V & $\begin{array}{l}\text { Terlapukkan } \\
\text { Seluruhnya }\end{array}$ & $\begin{array}{l}\text { Kondisi tubuh batuan seluruhnya menjadi tanah namun kondisi struktur batuan } \\
\text { masih terlihat baik atau utuh. }\end{array}$ \\
\hline VI & Tanah Sisa & $\begin{array}{l}\text { Kondisi tubuh batuan seluruhnya menjadi tanah dengan struktur batuan tidak } \\
\text { tampak dan terjadi perubahan volume secara signifikan yang belum tertransport }\end{array}$ \\
\hline
\end{tabular}

Sumber : Bieniawski (1989)

Tabel 2. Klasifikasi Keteknikan Batuan Berdasarkan

\begin{tabular}{cl}
\multicolumn{2}{c}{ Nilai RQD menurut Klasifikasi Deere } \\
\hline RQD \% & \multicolumn{1}{c}{ Keterangan } \\
\hline $90-100$ & Utuh \\
\hline $75-90$ & Baik \\
\hline $50-75$ & Sedang \\
\hline $25-50$ & Buruk \\
\hline $0-25$ & Sangat Buruk \\
\hline
\end{tabular}

Sumber : Bieniawski (1989)

Klasifikasi longsor yang dijadikan sebagai acuan adalah klasifikasi Hoek dan Bray (1981) yang membagi empat tipe longsoran berdasarkan bidang gelincirnya yaitu Longsoran bidang (plane failure), Longsoran baji (wedge failure), toppling failure dan circular failure (Gambar 1). Longsoran bidang merupakan longsoran yang dapat terjadi apabila massa batuan bergerak sepanjang lereng pada bidang gelincir. Longsoran baji adalah longsoran yang terjadi ketika terdapat dua bidang diskontinuitas yang berpotongan dan longsoran terjadi di sejajar bidang diskontinuitas tersebut sehingga membentuk membaji pada longsorannya. Toppling failure adalah jenis longsoran yang dapat terjadi jika pergerakan 
massa batuan tanpa melalui bidang gelincir dan sebagian besar perjalanan materialnya berada di udara. Circular failure merupakan jenis longsor yang terjadi pada batuan yang terlapukkan secara intensif, pada material lepas ataupun pada batuan dengan diskontinuitas yang rapat dengan orientasi tidak teratur.

Tabel 3. Klasifikasi Kuat Tekan Batuan Menurut Deere dan Miller

\begin{tabular}{cl}
\hline Kuat Tekan Batuan (MPa) & \multicolumn{1}{c}{ Keterangan } \\
\hline $1-25$ & Kekuatan Sangat Rendah \\
\hline $25-50$ & Kekuatan Rendah \\
\hline $50-100$ & Kekuatan Sedang \\
\hline $100-200$ & Kekuatan Tinggi \\
\hline$>200$ & Kekuatan Sangat Tinggi \\
\hline
\end{tabular}

Sumber : Bieniawski (1989)

Tabel 4. Kelas Massa batuan / rock mass rating (RMR)

\begin{tabular}{cll}
\hline Nilai RMR & Kelas & Kualitas Massa Batuan \\
\hline $81-100$ & I & Batuan Sangat Baik \\
\hline $80-61$ & II & Batuan Baik \\
\hline $60-41$ & III & Batuan Sedang \\
\hline $40-21$ & IV & Batuan Buruk \\
\hline$<21$ & V & Batuan Sangat Buruk \\
\hline Sumber : Bieniawski (1989) & &
\end{tabular}

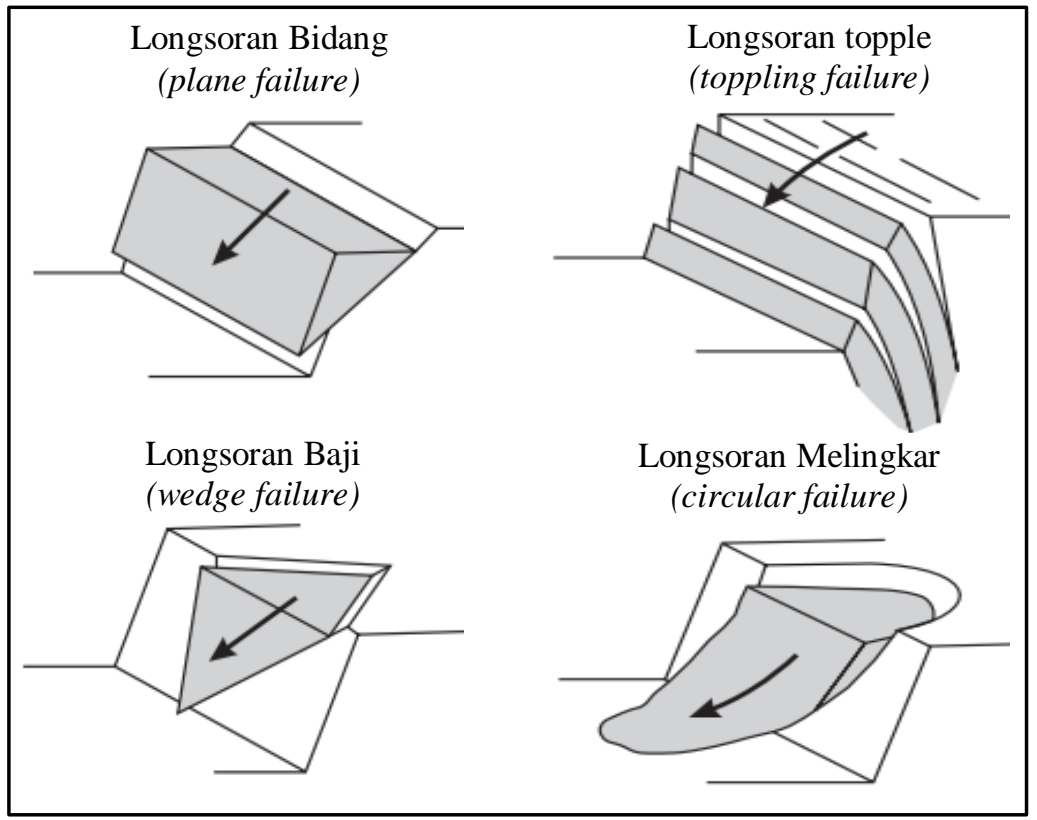

Gambar 1. Klasifikasi Longsor Berdasarakan Bidang Gelincir Sumber : Hoek dan Bray (1981)

\section{HASIL DAN PEMBAHASAN}

\section{A. Satuan Batuan}

Satuan batuan merupakan dasar suatau objek dasar dalam mengetahui sebaran geomekanika batuan, hal ini sibabkan karena setiap batuan memiliki tingkat kekuatan dan tingkat pelapukan yang berbedabeda yang sangat dipengaruhi oleh kandungan mineral bantuan selain juga dengan proses pembentukan dan tersingkapnya batuan tersebut. Daerah Patuk dan sekitarnya terdiri dari 3 satuan batuan, dari tua ke 
muda disusun oleh satuan batupasir tufan, satuan batupasir, dan satuan breksi andesit (Gambar 2). Kedudukan batuan di daerah ini memiliki jurus relatif berarah tenggara-barat laut dengan arah kemiringan relatif berarah barat daya-selatan. Pola struktur geologi pada satuan batuan tersebut merupakan bagian dari sayap antiklin dengan arah barat laut hingga tenggara serta memiliki kemiringan sayap ke arah selatan. Tingkat pelapukan batuan pada daerah tersebut berkisar 0,5 sampai 1 meter (Yanuardian et al., 2018).

Satuan batupasir tufan secara tatanan stratigrafi merupakan satuan batuan tertua di daerah patuk dan sekitarnya. Satuan ini tersebar di bagian utara dan timur laut daerah penelitian. Forrmasi ini berumur Oligosen-Miosen Awal. Satuan ini pada beberapa tempat dijumpai perselingan dengan batupasir dan tufa. Satuan batupasir tuffan memiliki hubungan selaras dengan satuan di atasnya yang berumur lebih muda yaitu satuan batupasir (Yanuardian et al., 2018).

Satuan batupasir merupakan satuan kedua paling tua yang ada di daerah penelitian. Keberadaan satuan batuan ini menempati di tengah daerah penelitian dengan pola sebaran dari timur ke barat. Satuan batupasir ini berumur Miosen Awal. Satuan Batupasir pada beberapa tempat terdapat perselingan tuffa andesitik, breksi pumice dan batu lempung tufan (Yanuardian et al., 2018).

Satuan breksi andesit merupakan satuan batuan termuda yang menyusun daerah penelitian. Hubungan stratigrafi satuan batupasir dan satuan breksi andesit adalah menjari. Satuan batuan ini berumur Miosen Awal. Satuan breksi andesit yang dijumpai di daerah penelitian dimungkinkan memiliki tipe yang sama dengan satuan breksi andesit di Gunung Api Purba Nglanggeran. Satuan breksi andesit ini pada beberapa tempat dijumpai perselingan dengan batu lempung, lava aglomerat, dan tufa (Yanuardian et al., 2018).

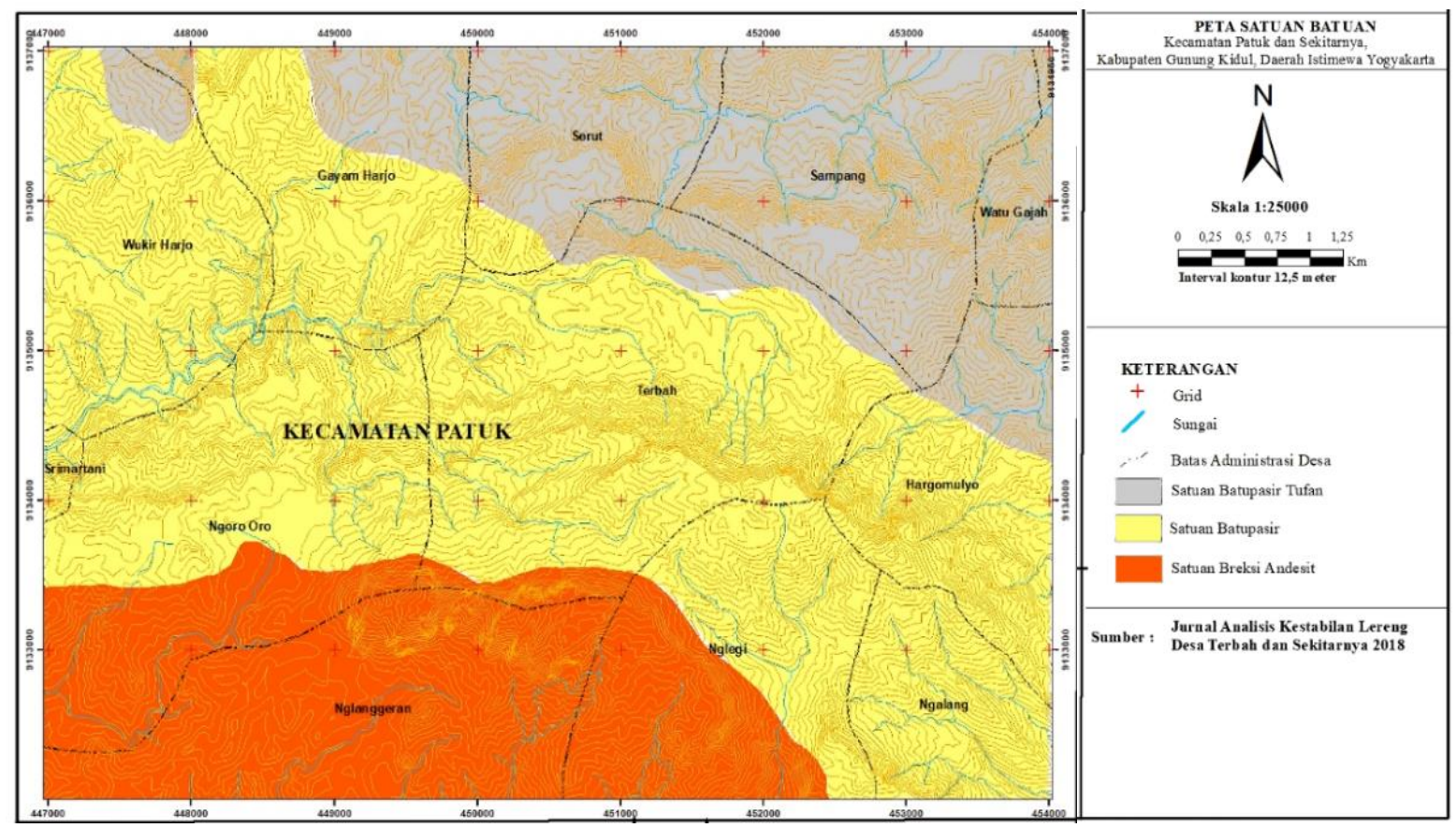

Gambar 2. Peta Satuan Batuan Kecamatan Patuk dan Sekitarnya Sumber : Yanuardian et al. (2018)

\section{B. Geomekanika Batuan}

Faktor geomekanika batuan yang dijadikan untuk mengelompokkan dari satuan batuan sebelumnya menjadi tiga bagian yaitu tingkat pelapukan, Rock Mass Quality (RQD), kuat tekan batuan, dan rock 
mass rating (RMR). Variabel pengelompokan tersebut membagi satuan batuan yang awalnya tiga menjadi lima satuan batuan berdasarkan sifat keteknikan batuan atau geomekanika batuan (Tabel 5). Satuan breksi andesit 1 tersusun mayoritas oleh breksi piroklastik hasil aktivitas vulkanisme gunung api. Batuan yang relatif resisten ini mengakibatkan batuan banyak dijumpai dalam kondisi tidak lapuk atau segar dengan warna abu-abu cerah. Sebaran dari lapukan pada satuan ini relatif sedikit dan ditemukan pada beberapa lokasi dengan warna pelapukan berwarna kemerahan. Tingkat pelapukan yang minim selaras dengan jumlah bidang diskontinuitas yang sedikit ditemukan pada satuan ini. Hal tersebut lalu dibuktikan dengan nilai RQD yang tergolong sebagai batuan utuh berkisar 98\% - 100\%. Satuan Breksi Andesit 1 memiliki kekuatan batuan low strength dengan nilai 29,16 MPa. Nilai RMR pada satuan breksi andesit 1 termasuk dalam kelas kualitas massa batuan sangat baik dengan nilai adalah 83 .

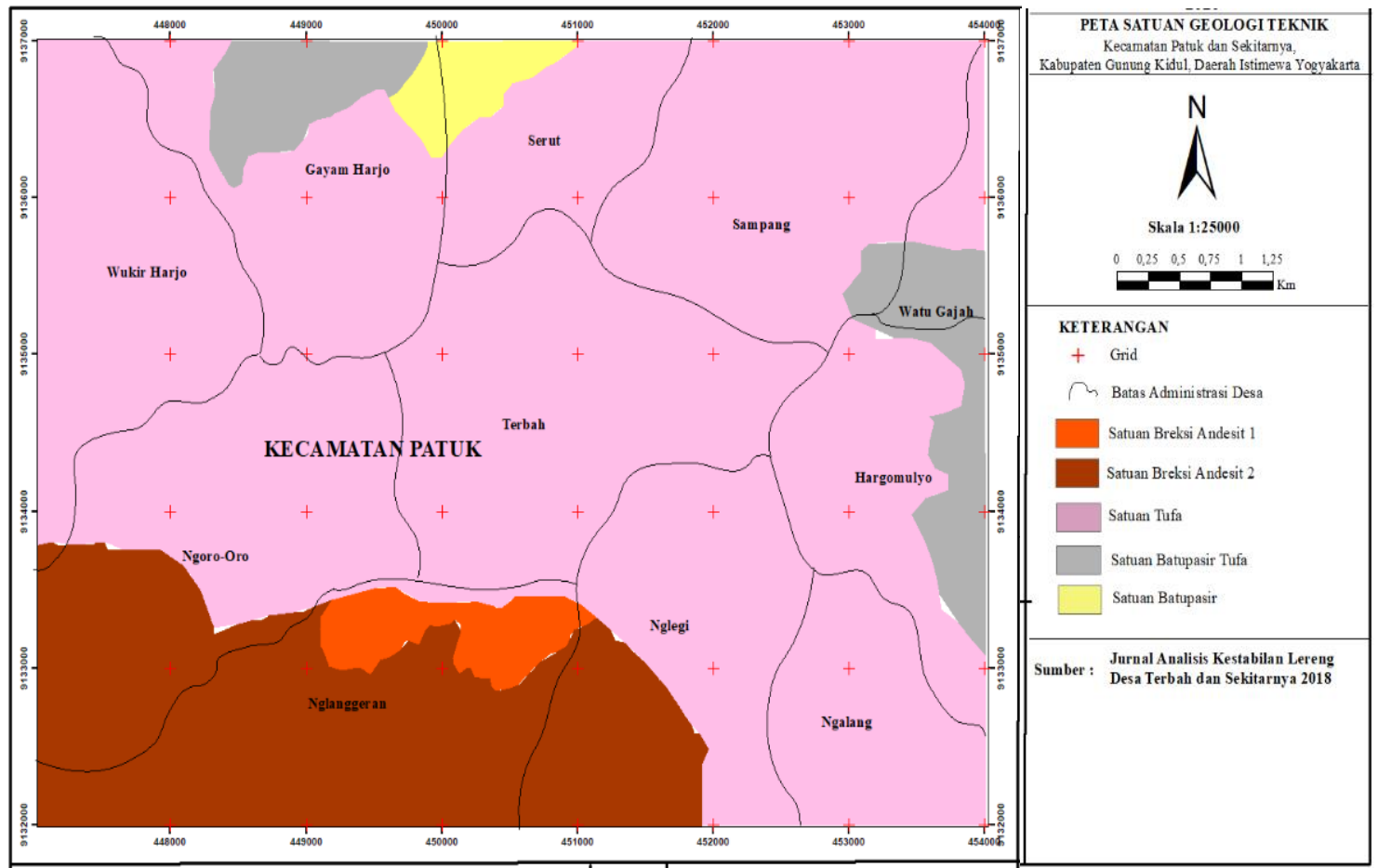

Gambar 3. Peta Satuan Geologi Teknik Kecamatan Patuk dan Sekitarnya Sumber : Yanuardian AR et al. (2018)

Satuan breksi andesit 2 ini didominasi oleh breksi piroklastik dengan tingkat pelapukan sedang, terlapukkan sebagian dan terlapukkan seluruhnya. Sebaran kekar pada satuan ini relatif ditemukan sedikit pada beberapa lokasi, sehingga mengakibatkan terjadi beberapa perbedaan dalam tingkat pelapukan. Hal ini kemudian di buktiakn dengan nilai RQD pada satuan ini berkisar 42\% - 76\% sehingga dan kuat tekan 4,9 - 30,4 Mpa yang tergolong sangat rendah - rendah. Derajat pelapukan dan nilai RQD yang bervariasai mempengaruhi nilai RMR pada satuan ini 48 - 55, yang termasuk dalam kategori kualitas massa batuan sedang.

Satuan tufa terdiri atas tufa dan lapili dengan tingkat pelapukan bervariasi yaitu segar, terlapukkan ringan, terlapukkan sedang, dan terlapukkan kuat. Variasi tingkat pelapapukan tersebut selaras dengan dijumpainya bidang diskontinuitas berupa kekar yang memiliki intensitas yang bervariasi dari sedang sampai sangat rapat. Hal ini kemudian membuat nilai RQD pada satuan ini $11 \%$ - $72 \%$ ikut bervariasi yang masih tergolong massa batuan dengan kualitas sangat buruk-sedang dan kekuatan batuan utuh pada 
satuan tufa antara 1,5 - 30,2 MPa sehingga termasuk sangat rendah - rendah. Nilai RMR pada satuan ini cukup bervariasi, antara 36 - 80 yang termasuk dalam kategori kualitas batuan buruk hingga baik.

Satuan batupasir tufan terdiri dari batupasir tufan dan sedikit sisipan lapili dengan kondisi lapuk sedang hingga kuat. Tingkat pelapukan mengakibatkan intensitas kekar tinggi hingga rapat. Hal tersebut berakibat nilai RQD yang tidak terlalu bervariasi pada satuan ini yaitu 36\% -66\% sehingga tergolong massa batuan sedang. Nilai RQD yang kecil umumnya terdapat pada litologi batupasir berbutir halus. Kekuatan batuan utuh pada satuan ini 4,5 - 34,5 Mpa yang tergolong sangat rendah sampai rendah. Nilai yang saling mendekati dari beberapa faktor diatas membuat nilai RMR satuan ini cukup stabil yaitu 53 - 63 yang termasuk dalam kategori sedang hingga baik.

Satuan batupasir terdiri atas batupasir dengan sedikit sisipan lempung dan tufa dengan tingkat pelapukan antara sedang hingga kuat. Tingkat pelapukan sedang hingga kuat berakibat pada intensitas kekar termasuk sedang dengan jarak spasi antar kekar cukup rapat. Namun dominasi kekar yang sedang mengakibatkan nilai RQD pada satuan ini tidak terlalu buruk atau berada pada nilai $46 \%$ - 58\% yang tergolong massa batuan sedang. Hal ini kemudian dibuktikan dengan nilai RMR dalam kelas kualitas massa batuan baik dengan nilai 62. Namun dengan kuat tekan batuan pada satuan 13,6 Mpa sehingga termasuk sangat rendah karena sifat batuan sedimen yang mudah menglami deformasi ketika ditekan.

Tabel 5. Parameter Nilai Geomekanika Setiap Satuan Batuan Di Kecamatan Patuk, Kabupaten Gunung Kidul

\begin{tabular}{lccccl}
\hline \multirow{2}{*}{ Satuan Batuan } & \multicolumn{3}{c}{ Parameter } & Tingkat & Ruat Tekan \\
\cline { 2 - 5 } & Pelapukan & RQD $(\boldsymbol{\%})$ & $\begin{array}{c}\text { RMR } \\
(\mathbf{M p a})\end{array}$ & $\begin{array}{c}\text { Kualitas Massa } \\
\text { Batuan }\end{array}$ \\
\hline Breksi Andesit 1 & I & $98-100$ & 29,16 & 83 & Sangat Baik \\
\hline Breksi Andesit 2 & III-V & $42-76$ & $4,9-30,4$ & $48-55$ & Sedang \\
\hline Tufa & I-IV & $11-72$ & $1,5-30,2$ & $36-80$ & Buruk-Baik \\
\hline Batupasir Tufan & III-IV & $36-66$ & $4,5-34,5$ & $53-63$ & Sedang-Baik \\
\hline Batupasir & III-IV & $56-58$ & 13,6 & 62 & Baik \\
\hline
\end{tabular}

Sumber : Yanuardian AR et al. (2018)

\section{Analisis Kinematika Jenis Longsor di Daerah Penelitian}

Analisis kinematika yang dilakukan pada batuan di daerah penelitian bertujuan untuk menentukan tipe longsoran yang berpotensi akan terjadi berdasarkan keadaan nilai geomekanika batuan (rock mass rating) yang telah didapatkan yang kemudian di kaitkan dengan jenis longsoran menurut Hoek dan Bray (1981) yang membagi empat tipe longsoran berdasarkan bidang gelincirnya. Penilaian keadaan geomekanika batuan pada daerah Patuk dan sekitarnya menggunakan 3 parameter yaitu tingkat pelapukan, tingkat keutuhan batuan yang dinyatakan dengan RQD, dan nilai kuat tekan batuan utuh. Tingkat pelapukan relatif bervariasi, mulai dari masih segar atau utuh hingga terlapukkan seluruhnya, hal itu dipengaruhi oleh keadaan topografi, serta bidang diskontinuitas pada daerah tersebut. Tingkat keutuhan batuan akibat kehadiran bidang diskontinuitas yang dinyatakan dengan nilai RQD juga menunjukkan nilai bervariasi yang dipengaruhi kehadiran struktur kekar. Nilai kuat tekan batuan utuh (MPa) pada daerah tersebut termasuk kategori sangat rendah sampai rendah yang dipengaruhi oleh sifat resistensi batuan dalam menerima beban tekanan. Pembobotan dari ketiga parameter tersebut menunjukkan pada daerah Patuk dan sekitarnya memiliki kualitas batuan buruk hingga sangat baik.

Potensi terjadinya longsor pada daerah penelitian didukung oleh topografi lereng yang relatif curam. Analisis keadaan geomekanika batuan diperlukan untuk memetakan jenis potensi longsor pada daerah penelitian. Secara umum potensi longsor yang terjadi pada daerah Patuk dan sekitarnya berjenis gelinciran (sliding). Gelinciran adalah gerakan menuruni lereng oleh suatu massa tanah dan atau batuan penyusun lereng, melalui bidang gelincir pada lereng atau pada bidang regangan geser 
berkembang paling intensif (Nugroho, 2010). Tidak semua satuan geoteknik batuan pada daerah penelitian memiliki potensi longsor. Satuan breksi andesit 1 termasuk dalam kondisi yang stabil terhadap longsoran, hal tersebut didukung oleh keadaan batuan yang segar seta kehadiran bidang diskontinuitas yang minim (RQD 98\%-100\%). Suatu batuan dalam keadaan utuh memiliki gaya tahanan yang kuat terhadap gaya penggerak batuan.

Satuan breksi andesit 2, satuan tufa, serta satuan batupasir tufa memiliki kualitas batuan buruk baik. Tingginya tingkat pelapukan, kehadiran bidang diskontinuitas yang rapat (RQD 11\% - 76\%), serta resistensi batuan yang lemah menjadi faktor utama potensi longsoran. Keadaan geomekanika tersebut menyebabkan potensi longsor gelinciran (sliding) dengan bentuk longsoran busur (circular failure). Bentuk longsoran ini memiliki karakter berupa massa rombakan yang bergerak berupa material lepas (tanah) dan dapat berupa massa batuan yang terfragmentasi akibat banyaknya bidang diskontinuitas yang berakibat pada mudah terpecahnya tubuh batuan dan mudahnya batuan mengalami suatau pelapukan. Sehingga karakter longsoran ini berupa massa yang bergerak berupa material lepas (tanah) sesuai dengan keadaan batuan dengan tingkat pelapukan tinggi atau intensif dan massa batuan terfragmentasi sesuai dengan kehadiran bidang diskontinuitas yang relatif rapat dan tidak teratur pada satuan batuan tersebut. Pada longsoran busur massa batuan yang bergerak dapat berupa material lepas seluruhnya.

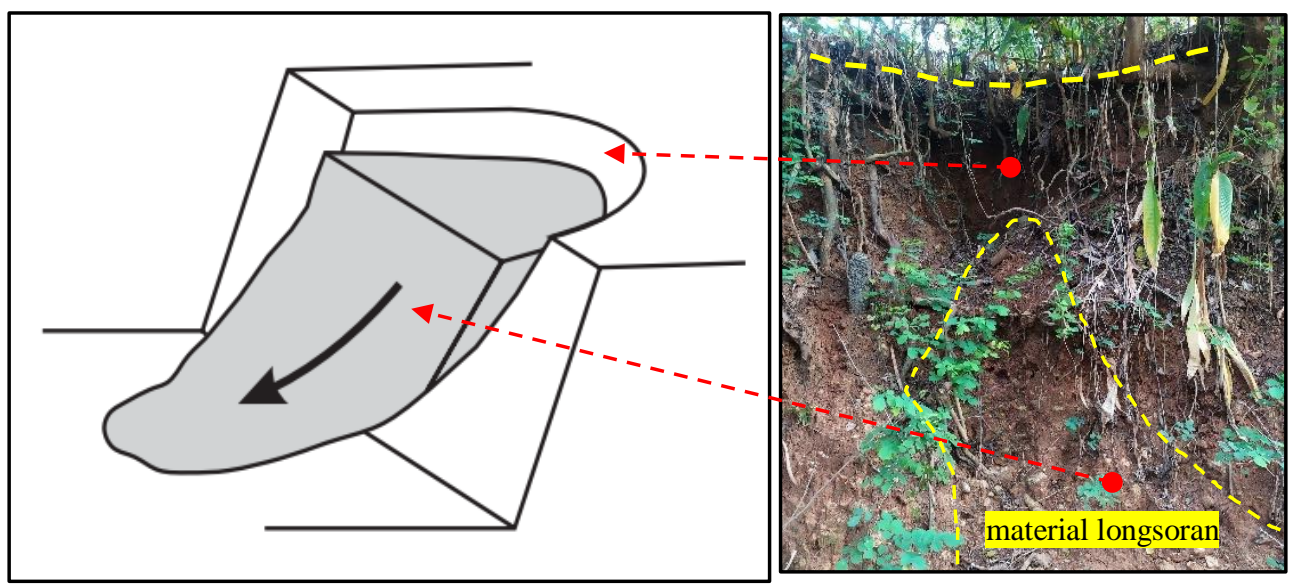

Gambar 4. Longsoran Busur (Circular Failure) Daerah Penelitian

Sumber : Penulis (2020)

Satuan batupasir dapat memiliki kualitas batuan yang tergolong baik. Tingkat pelapukan, kehadiran bidang diskontinuitas (RQD 48\% - 58\%), serta resistensi batuan relatif sedang sehingga tidak mendukung potensi longsor dalam perombakan massa seluruhnya. Keadaan geomekanika tersebut menyebabkan potensi longsor gelinciran (sliding) dengan bentuk longsoran bidang (plane failure) maupun longsoran baji (wedge failure). Kedua bentuk longsoran tersebut dapat digolongkan sebagai pergerakan block namun dalam bentuk berbeda. Longsoran bidang dapat terjadi apabila kemiringan bidang gelincir lebih kecil dari kemiringan lereng, arah perlapisan batuan atau bidang diskontinuitas sejajar dengan arah kemiringan lereng, serta gaya penggerak lebih besar dari gaya penahan batuan. Sehingga lokasi daerah dengan arah kemiringan lereng berarah barat daya-selatan yang sejajar atau searah dengan arah kemiringan batuan merupakan daerah yang berpotensi mengalami kelongsoran jenis ini. Potensi longsoran baji pada Satuan batupasir ini dapat terjadi apabila terdapat dua bidang diskontinuitas yang berpotongan dengan kemiringan garis perpotongan lebih kecil dari kemiringan lereng, serta bidang longsoran dibatasi oleh muka lereng, bagian atas lereng serta kedua bidang diskontinuitas. Satuan batupasir ini berdasarkan keadaan geomekanika batuan dapat berpotensi terjadi 
longsoran bidang (plane failure) dan longsoran baji (wedge failure) yang akan ditentukan oleh arah penjajaran bidang diskontinuitas dan kemiringan lereng yang ada pada suatu lokasi.
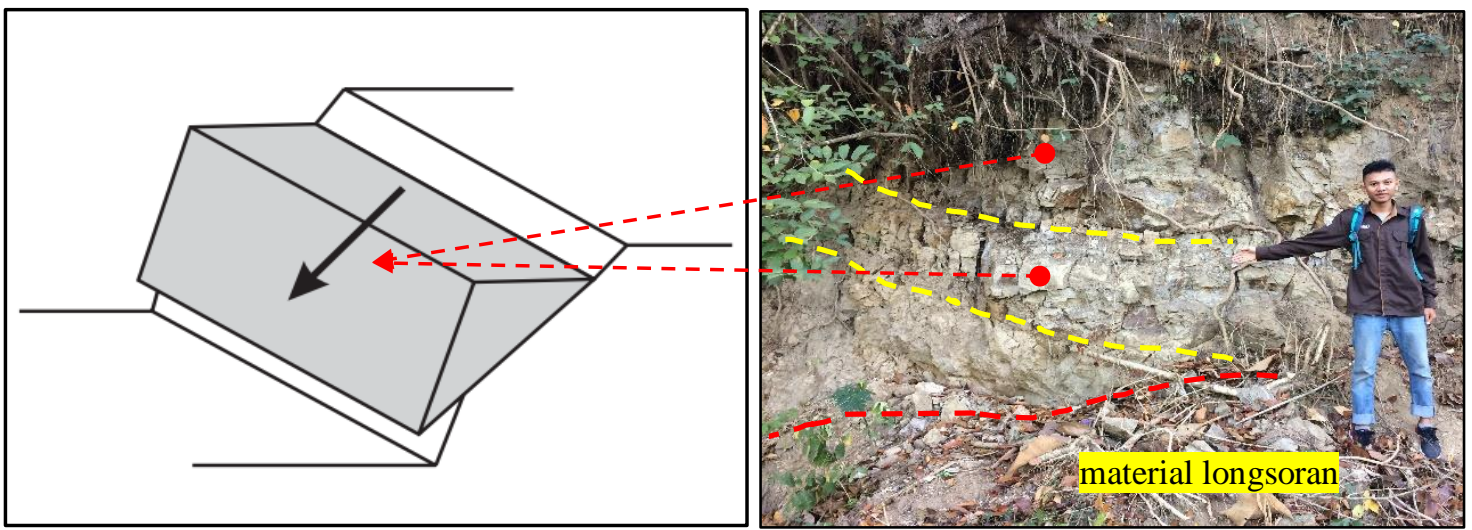

Gambar 5. Longsoran Bidang (Plane Failure) Daerah Penelitian

Sumber : Penulis (2020)
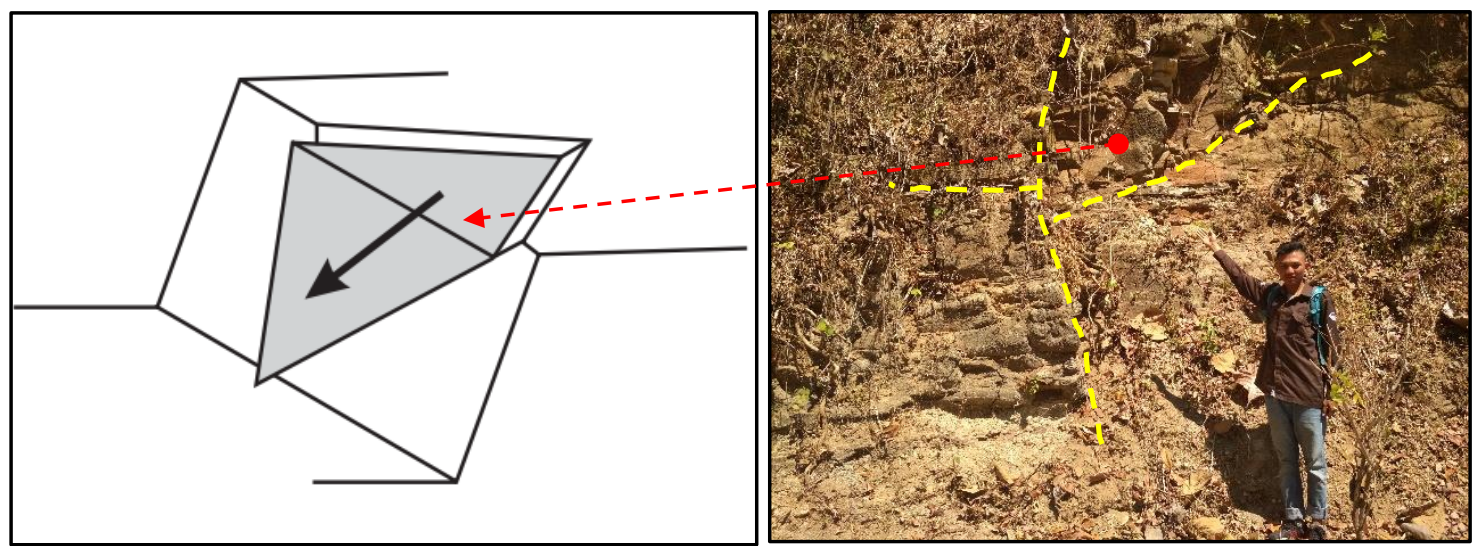

Gambar 6. Longsoran Baji (Wedge Failure) Daerah Penelitian Sumber : Penulis (2020)

\section{KESIMPULAN}

Daerah penelitian terletak di Kecamatan Patuk dan sekitarnya, Kabupaten Gunung Kidul, Provinsi Daerah Istimewa Yogyakarta. Tinggginya tingkat kejadian bencana tanah longsor pada daerah penelitian menjadi pertimbangan utama penentuan lokasi penelitian. Secara geologi daerah penelitian masuk kedalam tatanan kompleks pegunungan selatan. Terdapat 3 satuan batuan yang menyusun daerah penelitian, dari tua ke muda yaitu satuan batupasir tufan, satuan batupasir, serta satuan breksi andesit. Arah pelamparan (strike) batuan pada daerah penelitian relatif barat laut - tenggara dengan arah kemiringan relatif berarah barat daya - selatan.

Daerah penelitian dibagi menjadi 5 satuan geologi teknik berdasarkan RMR yaitu satuan breksi andesit 1 dengan kualitas batuan sangat baik (83), satuan breksi andesit 2 dengan kualitas batuan sedang (48-55), satuan tufa dengan kualitas batuan buruk - baik (36-80), satuan batupasir tufan dengan kualitas batuan sedang - baik (53-63) dan satuan batupasir dengan kualitas batuan baik (62).

Potensi jenis longsoran pada daerah Patuk dan sekitarnya berdasarkan analisis kinematika dari kondisi geomekanika batuan yaitu berjenis longsoran gelinciran (sliding) namun untuk satuan breksi andesit tergolong stabil dan tidak berpotensi terjadi longsoran. Longsoran gelinciran (sliding) pada daerah penelitian yaitu berbentuk longsoran busur (circular failure), longsoran baji (wedge failure), dan longsoran bidang (plane failure). Bentuk longsoran busur berpotensi terjadi pada satuan breksi andesit 
ii, satuan tufa, dan satuan batupasir tufa. Sedangkan bentuk longsoran bidang dan longsoran baji berpotensi pada satuan batupasir.

Tindakan mitigasi bencana perlu dilakukan pada daerah Patuk dan sekitarnya. Hal tersebut dilakukan untuk mengurangi ataupun meniadakan potensi bencana tanah longsor pada daerah penelitian. Perkuatan lereng dengan struktur berm, metode terasiring, serta memperhatikan arah pensejajaran bidang diskontinuitas dalam pemotongan lereng dapat meminimalisir potensi longsor pada daerah penelitian. Penyuluhan tentang tanggap darurat bencana tanah longor juga perlu diberikan pada masyarakat di daerah Patuk dan sekitarnya. Penyuluhan dapat memberikan edukasi mengenai tindakan yang harus dilakukan saat terjadi bencana tanah longsor, dengan kesiapan tersebut diharapkan dapat meminimalisir kerugian jiwa maupun materi.

\section{UCAPAN TERIMA KASIH}

Penulis mengucapkan terima kasih kepada Jurusan Teknik Lingkungan UPN Veteran Yogyakarta khususnya tim dosen pengampu Geotek Lingkungan yang telah memberi saran dan bantuan biaya dalam penulisan karya ilmiah ini sehingga penelitian dapat selesai dan berjalan lancar.

\section{DAFTAR PUSTAKA}

Anwar, H., Rai, M. A., Wattimena, R. K. (2018). Pengaruh Bidang Diskontinu terhadap Kestabilan Lereng Tambang - Studi Kasus Lereng Pb9s4 Tambang Terbuka Grasberg. Jurnal Geomine, 06(01) : 34-41. https://doi.org/10.33536/jg.v6i1.183

Arsyad, M. (2017). Modul Geologi Teknik Pelatihan Perencanaan Bendungan Tingkat Dasar. Bandung: Kementrian PUPR Badan Pengembangan SDM Pusat Pendidikan dan Pelatihan Sumber Daya Air dan Konstruksi.

Bieniawski, Z.T., (1989). Engineering Rock Mass Classifications: A Complete Manual for Engineers and Geologists in Mining, Civil, and Petroleum Engineering. Canada : John Illey \& Sons, Inc.

Dandy, M., Budianta, W., Setiawan, N. I. (2015). Petrologi dan Sifat Keteknikan Breksi dan Batu Pasir di Gedangsari, Gunung Kidul, Derah Istimewa Yogyakarta: Proceeding, Seminar Nasional Kebumian Ke-8 Academia-Industry Linkage 15-16 Oktober 2015 Grha Sabha Pramana. https://repository.ugm.ac.id/135495/

Dibi.BNPB. (2020). Kejadian Bencana Alam di Gunung Kidul dari Tahun 2000 - 2020. dibi.BNPB. Diunduh pada 10 Mei 2020.

Hirnawan, F. (2018). Geomekanika. Bandung: Fakultas Tenik Geologi Universitas Padjadjaran.

Hoek, E. and Bray, J. (1981). Rock Slope Engineering (3rd ed). London: Institution. Mining and Metallurgy

Karnawati, D. (2005). Bencana Alam Gerakan Massa Tanah di Indonesia dan Upaya Penanggulangannya. Yogyakarta : Jurusan Teknik Geologi Fakultas Teknik Universitas Gadjah Mada.

Kristanto, W. A. D., Astuti, F. A., Nugroho, N. E., Febriyanti, S. V. (2020). Sebaran Daerah Sulit Air Tanah Berdasarkan Kondisi Geologi Daerah Perbukitan Kecamatan Prambanan, Sleman, Yogyakarta. Jurnal Sains dan Teknologi Lingkungan 12 (01) : 68-83 https://doi.org/10.20885/jstl.vol12.iss1.art6

Nugroho, N. E., dan Kristanto, W. A. D. (2019). Kajian Tingkat Risiko Tanah Longsor Desa Hargomulyo, Kecamatan Kokap, Kabupaten Kulonprogo. Jurnal Ilmiah Lingkungan Kebumian 01(02) : 9-25

https://doi.org/10.31315/jilk.v1i2.3281

Nugroho, B. (2010). Pengaruh Struktur Geologi Terhadap Stabilitas Goa Seropan, Kecamatan Semanu, Kabupaten Gunung Kidul, Daerah Istimewa Yogyakarta. Seminar Fakultas Teknik Geologi Universitas Padjajaran. 
https://seminar.ftgeologi.unpad.ac.id/seminar/pengaruh-struktur-geologi-terhadap-stabilitas-goaseropan-kecamatan-semanu-kabupaten-gunung-kidul-daerah-istimewa-yogyakarta/

Titisari, A. D., Zaidini, H., Husna, K., Putra, I. D., Indrawan, I. G. B. (2019). Penentuan Zona Kerentanan Longsor Berdasarkan Karakteristik Geologi dan Alterasi Batuan. Jurnal Pengabdian kepada Masyarakat (04) 02: 141-158 https://doi.org/10.22146/jpkm.35935

Pangaribowo, W. S. (2020). Longsor dan Tanah yang Merekah Terjadi Dusun Brongkol Gunung Kidul. Yogyakarta: TribunJogja, http://jogja.tribunnews.com/2020/01/08. Dakses pada 14 Mei 2020.

Yanuardian, A. R., Indrawan, I. G. B., Warmada, I. W. (2018). Analisis Kestabilan Lereng Di Desa Terbah Dan Sekitarnya, Kecamatan Patuk, Kabupaten Gunung Kidul Berdasarkan Slope Stability Probability Classification. Journal RISET Geologi dan Pertambangan (28) 01 :101-114 http://dx.doi.org/10.14203/risetgeotam2018.v28.745 